\title{
Challenge and Opportunity to Implement the Right to Education for Child Refugees in Indonesia
}

\author{
Nugroho Adhi $\mathrm{P}^{1, *}$, I Gst Putu Agung ${ }^{1}$, Bernadette Gitareja ${ }^{1}$. \\ ${ }^{1}$ Universitas Gadjah Mada, Yogyakarta, Indonesia \\ *Corresponding author. Email: nugroho.a.p@mail.ugm.ac.id
}

\begin{abstract}
The right to education is one of all humankind's fundamental rights, regardless of their status. Thus, the right to education should also be available to refugees. The right of education for refugees is protected under the 1951 Refugee Convention, where party states should provide elementary education. Hence, it is an obligation to the state parties to ensure the rights of education for refugees in their jurisdiction area. As a state that has not ratified the Refugee Protocol, Indonesia has been a host for the 'refugee transit' before these refugees will be placed in their settlement countries. The type of this research is qualitative research with a legal-normative approach and descriptive-comparative nature. This type of research creates a description of empirical facts with normative analysis and comparing the existing refugees' right to education as variables by comparing Indonesia's practice with Thailand and Malaysia as the primary cases collected through literature review. Comparisons between a legal provision with other legal provisions, or a fact with other facts, with grammatical, systematic, and comparative interpretations would be identified and analyzed the legal implication for implementing the right to education. The result highlights three implication rights: there are no national laws in Indonesia that specifically regulate refugees' right to education. First, there are no national laws in Indonesia that specifically regulate the right of refugees to education. The absence of national laws in Indonesia created gaps between each country's national laws with various international legal instruments that regulate the right to education as one of the special rights of refugees and a part of human rights. Second, even in the absence of a legal framework, manifesting the right of education to the refugees' children is not impossible and can be achieved by empowering the Non-Government Organization (NGO) or even Community Based Organization (CBO) to provide alternative means of education. Third, since Indonesia has not ratified the 1951 Refugee Convention, it becomes the main barrier for Indonesia to fulfill refugee rights. Thus, we conclude by revising the existing legal framework by placing refugees as entities outside immigrants while adding content regarding fundamental rights. In this case, the right to education is one of the fundamental rights that should be guaranteed by the government.
\end{abstract}

Keywords: law, human rights, limited double citizenship.

\section{INTRODUCTION}

In recent years the world has seen much turmoil, in particular on security and political issues. These issues later contribute to the rise of conflicts worldwide. Conflicts in the Middle East such as in Syria and Yemen, and the Rohingya crisis in Myanmar, are examples of how many conflicts existed today. In 2020 alone, at least ten conflicts gained world attention, namely the conflict in Libya, Afghanistan, Ukraine, and numerous other conflicts happening in the Middle East and Africa [1]. The conflict threatens their people's lives, making it difficult for them to access fundamental rights and resulting in a mass of people fleeing from their country to search for a better life. The people leaving their country due to specific causes will be classified as refugees. The term "refugee" may vary. The 1951 Convention, for instance term 'refugee' is defined as a person who is outside the country of its citizenship and cannot or because of fear is unwilling to take advantage of the protection of its state by justified fear of being prosecuted for reasons of race, religion, nationality, membership in a particular social group or political opinion (Article I A (2) of [2]). The definition, however, is expanded by the Organization of African Unity, by adding a new element by adding the phrase "compelled to leave the country where he/she resides in order to seek refuge in another place outside his country of origin due to external aggression, occupation, or event that 
disrupts public order in his country of origin or nationality" (Article 1(2) of [3]). The inclusion of the phrase gives a broader scope of refugee, which is not limited to only people fleeing their country under the fear of being prosecuted and any political factor, but also includes those who flee their country under the fear of war and public order instability in their country.

Indonesia has a long history of dealing with refugee issues. Since the 1970s, Indonesia has become one of the parties involved in receiving refugees from Vietnam [4]. This later continues up to this time where Indonesia is still receiving refugees, particularly from conflict areas. Referring to the UNHCR, until December 2019, nearly 13.657 refugees from 45 countries are currently in Indonesia, with almost half of them coming from Afghanistan [5]. The number of refugees is potentially rising since Indonesia has become one of the transit states for refugees before continuing their desired country destination journey. In this case, Indonesia has become the transit for most maritime refugees seeking to go to Australia [6]. While residing in Indonesia, the refugee will be under the consent of the International Organization for Migration (IOM), the UN High Commissioner for Refugee (UNHCR), and to some extent, the Indonesian government. On the regional stage, Indonesia is not the only country that is dealing with the refugee issue. Alongside Thailand and Malaysia, Indonesia shows its initiative in responding to the refugee issue, especially during the Rohingya Crisis, which started in 2015 [7].

With the possibility of increasing refugee numbers, it should be noted that refugees often bring their families, including children, on their voyage. With the facts given, the children will be the concern of this research. A question arose. How would the transit government fulfill the refugee residing right in its jurisdiction, particularly how would the transit country manifest the refugee children's right to a proper education? Generally, countries based themselves on the guide stipulated under the 1951 Refugee Convention and its 1967 Protocol. However, as the transit country, Indonesia does not become a party to the convention and further resulted in Indonesia's not binding to the right stipulated in the convention and its protocol. The research will analyze the fulfillment of a refugee child's right to education as well as the challenge and opportunity in manifesting the right in Indonesia.

\section{RESEARCH METHOD}

The type of this research is qualitative research with a legal-normative approach and descriptivecomparative nature. This type of research creates a description of empirical facts with normative analysis using primary and secondary sources of law. Data are gathered by document analysis as well as document screening and literature review. Further compares the data with existing refugees' right to education as variables by comparing Indonesia's practice with Thailand, Malaysia, and Australia. After the prerequisite data and the legal source has been obtained, it will be interpreted in light of the legal issue obtained and will answer the fulfillment of refugee's child right to education as well as its challenge and opportunity in the Indonesian context.

\section{FINDINGS AND DISCUSSION}

\subsection{Right to Education in International Law}

Indonesia has acknowledged the right to education through international conventions. Several international norms obliged Indonesia to fulfill and ensure that every person in their state could achieve those rights provided by the state.

\subsubsection{Universal Declaration of Human Rights}

Everyone is entitled to all the rights and freedom of education. As an aspect under this Declaration, article 2 of the UDHR ensures that no one can be hampered towards education (Article 2 of [8]). The right to education is firmly established in international agreements such as the UDHR. Where it has reinforced covenants, conventions, declarations, and frameworks relating to education, human rights, and the rights of children in the past decades, as an example, the Declaration of the Rights of the Child (1959), International Covenant on Economic, Social and Cultural Rights (ICESCR) (1966) and Convention on the Rights of the Child (CRC) (1989) [9]. The UDHR upholds protection where everyone has the right to free education in at least elementary and fundamental stages (Article 26 (A) of [8]).

\subsubsection{International Covenant on Economic, Social and Cultural Rights (ICESCR)}

Indonesia ratified the International Covenant on Economic, Social, and Cultural Rights. This creates protection for refugees and asylum seekers within the jurisdiction area of Indonesia (No. 3 of [10]). Rights protected under this Covenant require states to respect refugees' economic, social, and cultural 
rights (No. 3 of [11]). Those rights are considered core obligations that should be preserved in all circumstances to all people under the State's effective control (No. 9 of [10]). Core obligations of the State should not be restricted based on a person's nationality or legal status (No. 9 of [10]).

\subsubsection{Convention on Rights of the Child}

The non-refoulment principle is an intersection between the 1951 Refugee Convention and the Conventions on Rights of the Child (Article 33 of [11]). In 2015 only 51 school-age refugee children in Indonesia were enrolled in public schools, representing less than $10 \%$ enrolment in formal education [12]. With the number of 612 separated and unaccompanied children In Indonesia [12], an obligation to protect the child's rights, including health and social welfare, arises (Number 29 of [13]). Henceforth, in line with articles 28 and 29 of the Convention on the Rights of the Child, states should give access to education during all phases of the displacement cycle (Number 41 of [13]).

There is a crucial obligation to register the children with appropriate school authorities as soon as possible and get assistance in maximizing learning opportunities (Number 42 of [13]). The aim is to provide these children with school certificates or other documentation indicating their education level and to assure the development to maintain their cultural identity and values (Number 42 of [13]).

\subsubsection{Convention against Discrimination in Education 1960}

In article 2 of the Convention against Discrimination in Education, it is prohibited to deprive a person's right to education. This article provides compliance to the refugee's right to education. It is mentioned that discrimination includes distinction, exclusion, limitation, or preference that deprives or limits any person or group to education based on nationality (Article 2 of [14]). Despite their status as a refugee, rights of education still apply to them without exception.

\subsection{Refugee Right to Education in Transit Countries: Malaysia and Thailand Practices}

As mentioned above, Indonesia is not the only country that has become a transit country for refugees. Along with Thailand and Malaysia, Indonesia is the transit country and continuously receives a number of refugees beyond their territories at the regional level. Furthermore, the practice of Malaysia and Thailand are as follows:

\subsubsection{Malaysia}

Malaysia is neither a party to the 1951 Refugee Convention nor its 1967 Protocol. Although not a party to the Convention, Malaysia has become the host for more than 178,990 refugees, with the majority of the refugees are the Rohingyas [15]. So far, Malaysia has become the largest Rohingya refugee hoster at the regional level and the fourth largest on the world stage [16]. The absence of relevant convention in Malaysia's jurisdiction would raise questions on how Malaysia managed the refugees resided in its territory.

The positive law of Malaysia also classifies the refugees as 'illegal migrants,' making them subject to criminalized and may be detained, arrested, and even deported for violating the Immigration Act where it is prohibited for alien to enter Malaysia at an unauthorized entry point or entering Malaysia without document such as passport, or even using and possession false documents upon entrance to Malaysia [17]. Furthermore, under the act as a refugee, it should be noted that refugees flee their countries upon circumstances, making it difficult to access and obtain the required document since their main concern is their own safety rather than their document. Thus, resulting in the Rohingyas being detained or even neglected by the Malaysian authorities since they are considered to violate the provisions of the act. The Malaysian government at the 36th ASEAN Summit has declared its intention to no longer accepting Rohingya refugees (Sections $5,6,15,56$ of [17]). This makes it difficult for refugee rights to be fulfilled.

In particular, the right to education is important since nearly 60.000 of the Rohingya refugees are children below the age of 18 [15]. Besides, any Rohingya born in Malaysia are also not considered Malaysian citizens since Malaysia does not adopt the principles of Ius Soli, making them inherit their parent's statelessness. This condition challenges refugee's access to formal education in Malaysia [15][18]. In the absence of formal education, 
informal education organized by the UNHCR, Community Based Organizations (CBO), other NonGovernmental Organization learning centers, and even empowered Madrasah to accommodate the child of the Rohingya which religion are majorly Muslim [15]. Furthermore, some of the NGOs and CBO have shown their success in providing education to the children, such as the Sekolah Komuniti Rohingya and the United Arakan Institute Malaysia [15]. Unfortunately, it should be noted that NGO and CBO-funded activity is limited due underfunding constraints, making them lack proper classrooms, teachers, and even teaching materials [15]. Besides funding, usually, independent education platforms established either by NGOs or the CBO often lack legal protection.

In contrast, a platform should be registered in the Ministry of Education to equalize the formal education platform [15]. Since the children attended the NGO's alternative education and the $\mathrm{CBO}$ which are not registered, they are not allowed to enter public school or even access to the labor market [15]. Although several challenges are faced by informal education, it should be noted that local communities and NGOs' empowerment proved to be essential in providing education for the refugee children who do not have proper access to education.

\subsubsection{Thailand}

Thailand is also not a party to the 1951 Refugee Convention and its 1967 Protocol. Unlike Malaysia, Thailand guarantees the right of education to all children with free basic education for 15 years, starting from pre-school until senior high school [19]. However, there are some concerns that refugees and migrant children are having a barrier in accessing formal education in Thailand. one of the barriers is the Language barrier. Since most of the school required Thai language proficiency, making it difficult for refugees, which is not native to the Thai language, to enroll in the school [20]. Besides, Children would have difficulty in learning a new language since the children either prefer using their mother tongue as the primary language or even have not learned the new language. The language barrier is faced when dealing with the refugee's children in the Myanmar-Thailand border, whereas the refugees coming from Myanmar are bound to use their language, and the education they receive before entering Thailand is mostly taught in Burmese [21]. Although the children are prepared in the refugee camps, their curriculum is local. It is bound with the children's ethnicity or language, making it difficult for them to continue their education after leaving the camp [21]. Besides language, the children are often stigmatized as rebels due to their ethnicity, which is associated with their struggle for independence and self-determination in Myanmar [21]. This stigma hampers their way to assimilate with society.

\subsection{Challenge and Opportunity on The Implementations of Right to Education to Children Refugees at The Level of Indonesian norms}

\subsubsection{Quo Vadis Regulation on Refugees in Indonesia}

Indonesia is not a State Party to the 1951 Convention and 1967 Protocol, and until now, Indonesia has not had a national legal instrument that explicitly protects refugee rights. The handling of refugees and asylum seekers in Indonesia has been carried out based on humanitarian reasons [22]. In its development, the arrival and presence of foreigners as an illegal immigrant who later declared themselves an asylum seeker (asylum seekers) and refugees (refugee) in Indonesia increasingly has led to various effects in the field of ideology, political, economic, social, cultural, and national security. To minimize this impact, on September 17, 2010, the Directorate General of Immigration at the Ministry of Law and Human Rights of the Republic of Indonesia issued a Regulation of the DirectorGeneral of Immigration No. IMI-1489.UM.08.05 of 2010 on Illegal Immigrants Management, which provides similarity and uniformity of regulatory directions in handling and treatment by immigration. In the Director-General of Immigration Regulation No. IMI-1489.UM.08.05 of 2010 on Illegal Immigrants Management defines illegal immigrants as foreigners who enter and reside in Indonesian territory not under the provisions of laws and regulations (Article 1 No. 1 of [23]), and the Government of Indonesia together with UNHCR Indonesia will provide protection and assistance to refugees and asylum seekers based on the Memorandum of Understanding (Article 1 No. 2 of [23]). Henceforth, the Director-General of Immigration Regulation No. IMI-1489.UM.08.05 of 2010 on Illegal Immigrants Management recognizes the status and documents issued by UNHCR for refugees and asylum seekers.

In early 2016, this regulation was replaced by the Director-General of Immigration Regulation No. IMI-0352.GR.02.07 of 2016 on the Illegal Immigrants Claiming to be Asylum Seekers or Refugees Management, which provides more limited space for protection [24]. The DirectorGeneral of Immigration Regulation No. IMI- 
0352.GR.02.07 of 2016 allows Immigration Administrative Action for refugees or asylum seekers holding documents issued by UNHCR who are not domiciled in Indonesia (Article 14 of [25]). Immigration Administrative Action is an administrative sanction (Article 75 of [26]) determined by the Immigration Officer against foreigners outside the court process (Article 1 No. 31 of [27]).

Law Number 37 of 1999 on Foreign Relations states that the authority to grant asylum to foreigners is in the hands of the President with due observance of the Minister's considerations (Article 25 of [28]) and is implemented under national laws and regulations and with due observance of international laws, customs and practices (Article 26 of [28]). Carrying out the mandate of Article 27 paragraph (2) of Law Number 37 of 1999 on Foreign Relations, on December 31, 2016, the President of the Republic of Indonesia, Joko Widodo, signed Presidential Regulation Number 125 of 2016 on Refugees from Abroad Management to fill the void laws regarding the arrangement of refugees and asylum seekers in Indonesia [29]. Presidential Regulation Number 125 of 2016 on Refugees from Abroad Management is aimed at dealing with refugees from abroad in 3 fundamental aspects, namely: first, effective handling and coordination in the field; second, respect for human rights; and third, the aspect of supervision of foreigners and state security [30]. However, Presidential Regulation Number 125 of 2016 on Refugees from Abroad Management is only limited to regulating mechanisms for dealing with asylum seekers and refugees who enter Indonesia, especially in emergencies [7].

Presidential Regulation Number 125 of 2016 on Refugees from Abroad Management defines Refugees from Abroad or Refugees as foreigners residing in the territory of the Unitary State of the Republic of Indonesia due to reasoned fear of persecution on the grounds of race, ethnicity, religion, nationality, social groups, and different political opinions who want the protection of their country of origin and/or have obtained asylum seeker or refugee status from the United Nations through UNHCR (Article 1 No. 1 of [31]). Therefore, Indonesia's handling of refugee affairs is carried out based on cooperation between the central government and the United Nations through UNHCR and/or international organizations (Article 2 No. 1 of [31]). Refugees found on Indonesian land territory will be reported to the Indonesian National Police for security, and then the refugees will be handed over to the Immigration Detention Center.
Furthermore, the Immigration Detention Center will coordinate with the local district/city government to bring and place refugees from where they are found to shelters.

Law Number 6 of 2011 on Immigration does not recognize the terms refugees and asylum seekers, and therefore refugees and asylum seekers will be considered illegal immigrants [31]. Most refugees entered Indonesian territory illegally by violating the immigration law in force in Indonesia and without any valid immigration documents [32]. In the context of asylum seekers and refugees, Law Number 6 of 2011 on Immigration defines a foreigner as a person who is not an Indonesian citizen (Article 1 No. 9 of [26]). Refugees and asylum seekers are considered illegal immigrants or foreigners placed in an Immigration Detention Center if they live in Indonesian territory without a valid or valid residence permit (Article of 83 [26]).

From the explanation above, several conclusions can be drawn, such as that the regulation of regulations in Indonesia regarding refugees has not been maximized, the occurrence of misunderstandings in placing refugees and immigrants within the scope of the same definition is a common mistake that can be found at various regulatory levels in Indonesia. Henceforth, the regulation regarding refugees is still in the context of an emergency and only contains regulations regarding refugee handling procedures, which do not contain refugees' fundamental human rights.

\subsubsection{The Regulation of the Right to Education to Child Refugees in Indonesia}

In Indonesia, the right to education is a fundamental right that is guaranteed in Article 31 of the 1945 Constitution. "(1) Every citizen has the right to education ...". In line with the regulation in Article 5 paragraph (1) of Law no. 20 of 2003 on the National Education System, "Every citizen has the same right to obtain quality education" even though the interpretation of citizens is still an obstacle in contextualizing the provision of educational rights for child refugees because citizens only imitate it. However, other regulations contain a scope that can be said to be contradictory to the two provisions above. This can be found in Law No. 39 of 1999 on Human Rights. Article 12: "Every person has the right to protection for his personal development, to obtain an education, to educate himself, and to improve his quality of life so that he becomes a human being who is faithful, devout, responsible, 
noble, happy and prosperous following human rights." Article 60 section (1): "Every child has the right to receive education and teaching in the framework of personal development according to his interests, talents, and level of intelligence." In this case, children are defined in Article 1 (5) where the child is any human being under 18 (eighteen) years of age and is not married, including children who are still in the womb if it is in his interest. This provision can then be an opportunity to justify that the right to education is not only limited to Indonesian citizens.

As explained in the previous paragraph, the statutory level does not explicitly state refugees guaranteed, especially in the Right to Education. Indonesia has determined its responsibility to guarantee based on a sense of humanity, which is then reflected in a technical arrangement in the form of a Circular Letter from the Ministry of Education and Culture Number 75253/A.A4/HK/2019 on Education for Children Refugees issued on July 10, 2019 (hereinafter referred as Circular Letter on Education for Children Refugees). With the following conditions:

1.) The fulfillment of the right to education must not be a burden on the Local Government Budget (APBD) or the State Budget (APBN).

2.) Must prioritize the completion of the right to education for Indonesian citizens.

3.) The education office coordinates children refugees' placement in education units in its territory and reports to the Ministry of Education and Culture by the Bureau of Planning and Foreign Cooperation, Secretariat General of the Ministry of Education and Culture.

4.) Admission of students who come from refugees must meet the following requirements:

a.) Have a refugee card issued by UNHCR.

b.) Obtain a recommendation from the local Immigration Detention Center in collaboration with the Ministry of Law and Human Rights.

c.) Receive a letter of guarantee and commitment of support from the sponsoring institution for each child who will go to school.

d.) Recommendation letter from the sponsoring institution.
5.) For students from refugees who have completed their education level at a circular time. With its authority, the education office can provide a certificate that students from child refugees have studied at the education unit concerned.

6.) The certificate in number 5 cannot be used to grant status, carry out affairs, and any transaction.

From these regulations, the Indonesian government has shown its good faith in guaranteeing children refugees' right to education. However, in this article, the author will provide some analysis regarding this circular letter force. In Indonesia's legal system, the circular letter is not included as a category of prevailing Laws. The circular letter does not fulfill the elements as legal norms (does not contain provisions regarding prohibitions, orders, permits, exemptions, authorities, both official and unofficial, and determinations) [33]. Nevertheless, the validity of circular letters must still be considered valid as long as they do not contradict higher laws and regulations while still considering juridical, philosophical, and sociological aspects in their formation and implementation (Article 8 No. 1 of [34]).

\subsubsection{Challenge and Opportunity to The Implementations of Right to Education in Indonesia}

In Indonesia, to enter a public primary school, the school has administrative requirements that prevent refugee children or asylum seekers from being registered. The complete documents are often not owned by refugees, to language barriers ranging from Indonesian for everyday learners to English for use in third countries later [35]. Regarding these obstacles, Arie Afriansyah, Ph.D., in his presentation on the Handling of Asylum Seekers and Refugees in Indonesia at the Seminar on Strengthening the Implementation of Presidential Regulation Number 125 of 2016 on Refugees from Abroad Management and Rudenim Functions held by the Jakarta Rudenim, said:

"Indonesia has ratified the Convention on the rights of the child and its core principle is the best interest of the child. So, Indonesia must be committed to carrying out its obligations, see what good the child is, and, ideally, the best for children in school, have access to education, and is hampered by administrative processes, so government policies must condition it. For 
example, the making of special regulations for refugees and asylum seekers in terms of registering, to carry out Indonesia's obligations" [36].

Henceforth, in practice, the granting of the right to education is still ongoing. As Slamet Wahyuni, as Head of the Jakarta Rudenim Care and Health Section, stated that the right to education of children is being fulfilled with the help of students or from community institutions who voluntarily help teach English, Indonesian, and handicrafts. For 2017, the Jakarta National Defense Forces collaborated with the University of Indonesia Crisis Center (PusKris UI) and also IOM to provide courses such as English, computers, and music, for the music taught is a guitar. Meanwhile, for refugees in the community house, Slamet Wahyuni also explained that the detainees cooperate with the education office to go to public primary schools, even though the refugees do not get a certificate. For refugees who are not accepted to attend public schools, they receive education from home-schooling and IOM funds [36].

The Semarang Rudenim also applies the same. According to Pandu Candra Brata, as the Head of the Section for Care and Health of the Semarang Rudenim, child refugees' education in Semarang's detention centers is programmed regularly. It is held once a week for each program, namely English lessons. Indonesian language lessons, and Handicrafts where IOM covers all program funding [36]. Furthermore, several students from universities in Semarang have indeed organized programs for refugees. One of them was a student from the Soegijapranata Catholic University in the psychology program who came and taught about character building for refugees, teenagers, and children. Thus, based on the description above, it can be seen that the Indonesian government has tried to fulfill the right to education of children by the CRC and has tried to carry out state obligations for these refugees and asylum seekers. The fulfillment of children's education rights generally includes English and Indonesian lessons. Other than that, it depends on the detention policy in which they are registered. Unlike the rudenim, for refugees who have been transferred to community houses, their children's educational rights can be fulfilled with IOM's assistance and cooperation with the education office to enroll them in public schools, even though they cannot get a certificate. For those who cannot attend formal schooling, IOM also provides a home- schooling program for child refugees. The children's best interests can be fulfilled, and later the three are transferred to a third country, they will not miss their lessons and can continue their life again [36].

From the explanation above, it can be concluded that granting the right to education has been carried out by several parties in Indonesia. There are still challenges, mostly related to the absence of regulations that can guide administrative matters that often the bureaucracy still equates refugees and ordinary students. Besides, third parties, such as IOM, UNHCR, students, and non-governmental organizations, are also significant in helping fulfill the right to education for refugee children refugees.

\section{CONCLUSION}

The right to education is one of the fundamental rights entitled to every individual regardless of her/his background. However, refugees who are leaving their country and currently residing in transitional countries are often neglected and deprived of their rights, particularly their education rights. It is an international obligation for states to ensure refugees' right to education in their state jurisdiction.

Indonesia still has regulatory constraints in its regulation, especially regarding the confusion regarding refugees' definition, which is still synonymous with immigrants. Besides, there are no regulations that guarantee the rights of refugees. However, in practice, efforts to realize this right have begun to be carried out by Indonesia with the existence of a Circular on Education for Refugee Children and also the method of providing educational assistance carried out at Rudenim and Community Housing from the management and third parties such as international organizations, students, and non-governmental organization.

\section{REFERENCES}

[1]. Robert Malley, "10 Conflicts to Watch in 2020.International Crisis Group," (2019). https://www.crisisgroup.org/global/10conflicts-watch-2020. Accessed on 15 October 2020.

[2]. The 1951 Convention relating to the Status of Refugees.

[3]. Convention Governing the Specific Aspect of Refugee Problems in Africa.

[4]. Tom Brown and Antje Missbach, "The Boats May Have 'Stopped', but More Refugees are Stuck in Limbo in Indonesia," The Conversation.

(2016). 
http://theconversation.com/the-boats-mayhave-stopped-but-more-refugees-are-stuckinlimbo-in-indonesia-56152, accessed on 18 October 2020.

[5]. The UN High Commissioner for Refugee (UNHCR), "UNHCR di Indonesia," https://www.unhcr.org/id/unhcr-di-indonesia. Accessed on 16 October2020.

[6]. Department of Immigration and Border Protection, "Indonesia as a Transit Country in Irregular Migration to Australia," Australian Government, (2014), p.4.

[7]. Dewansyah. Bilal, and Handayani, Irawati. "Reconciling Refugee Protection and Sovereignty in ASEAN Member States: Law and Policy Related to Refugee in Indonesia, Malaysia, and Thailand," Central European Journal of International and Security Studies, No. 4, 2018, p. 474-485.

[8]. Universal Declaration of Human Rights.

[9]. Tristan McCowan, "Reframing the Universal Right to Education," Comparative Education, Vol. 46, No. 4, 2010, p. 511.

[10]. The Duties of States Towards Refugees and Migrants under the International Covenant on Economic, Social and Cultural Rights, E/C.12/2017/1

[11]. UN Committee on the Rights of the Child (CRC), General comment No. 6 (2005): Treatment of Unaccompanied and Separated Children Outside their Country of Origin

[12]. United Nations High Commissioner for Refugees (UNHCR) Indonesia Factsheet October 2016. https://www.unhcr.org/protection/operations/ 50001bda9/indonesia-fact-sheet.html.

Accessed 19 October 2020.

[13]. UN Committee on the Rights of the Child (CRC), General comment No. 6 (2005): Treatment of Unaccompanied and Separated Children Outside their Country of Origin, number 29. 1 September 2005, CRC/GC/2005/6, available at: https://www.refworld.org/docid/42dd174b4.h tml. Accessed 19 October 2020.

[14]. Convention Against Discrimination in Education.

[15]. Julia Palik, "Education for Rohingya Refugee Children in Malaysia," Peace Research Institute Oslo (PRIO), Policy Brief 02, 2020. pp.2-3

[16]. Piya Sukhani,"The Shifting Politics of Rohingya Refugees in Malaysia," The Diplomat, July $10 \quad 2020$. https://thediplomat.com/2020/07/the-shiftingpolitics-of-rohingya-refugees-in-malaysia/. Accessed on 16 October 2020.
[17]. Malaysia 1953/1969 Immigration Act (Act $155)$.

[18]. UNHCR, "Education in Malaysia," (2020), https://www.unhcr.org/education-inmalaysia.html. Accessed on 17 October 2020.

[19]. UNICE, "Thailand Education Overview," https://web.archive.org/web/2017111407504 0/https://www.unicef.org/thailand/education_ 303.html. Accessed on 18 October 2020.

[20]. Thithimadee Arphattananon, "Education that Leads to Nowhere: Thailand's Education Policy for Children of Migrants," International Journal of Multicultural Education, Vol.14, No. 1, 2012. pp. 7

[21]. Save The Children, "Keeping the Promises," endorsed by CCSDPT, (2018). pp. 2-3.

[22]. Yohpy Ichsan Wardana, et al., "Handling Asylum Seekers and Refugees in Legal and Policy Contexts, Directorate of Human Rights and Humanities," (2015), Ministry of Foreign Affairs of the Republic of Indonesia, Jakarta, p. 36

[23]. Director General of Immigration Regulation No. IMI-1489.UM.08.05 of 2010 on Illegal Immigrants Management.

[24]. United Nations High Commissioner for Refugees Indonesia, Submission by the United Nations High Commissioner for Refugees for the Office of the High Commissioner for Human Rights' Compilation Report Universal Periodic Review: 3rd Cycle, 27th Session Indonesia, September 2016, United Nations High Commissioner for Refugees Indonesia, Jakarta, p. 4

[25]. Director General of Immigration Regulation No. IMI-0352.GR.02.07 of 2016 on Illegal Immigrants who Claim themselves as Asylum Seekers or Refugees Management.

[26]. Law of the Republic of Indonesia Number 6 of 2011 on Immigration.

[27]. Law of the Republic of Indonesia Number 6 of 2011.

[28]. Law of the Republic of Indonesia Number 37 of 1999 on Foreign Relations.

[29]. SUAKA, " Press Release SUAKA: Perpres RI no.125/2016 tentang Penanganan Pengungsi Dari Luar Negeri” https://suaka.or.id/2017/01/18/press-releasesuaka-perpres-ri-no-1252016-tentangpenanganan-pengungsi-dari-luar-negeri/, accessed on October 18, 2020.

[30]. Penny Naluria Utami, "Implementasi Peraturan Presiden Nomor 125 tahun 2016 tentang Penanganan Pengungsi dari Luar Negeri di Provinsi Kepulauan Riau," Jurnal 
Legislasi Indonesia, Vol. 16, No. 3, September 2019, p. 299-312

[31]. Presidential Regulation Number 125 of 2016 on Foreign Refugee Management.

[32]. Dita Liliansa and Anbar Jayadi, "Should Indonesia Accede to the 1951 Refugee Convention and its 1967 Protocol?," Indonesia Law Review, Vol. 5, No. 3, September - December 2015, p. 324-346

[33]. M. Solly Lubis, "Shifting Political Lines and Legislation Regarding Local Government," Alumni, Bandung, p. 8

[34]. Law of the Republic of Indonesia Number 12 of 2011.

[35]. Aprianus, S., 2020, "Contrast of the Fate of Two Refugee Children in Indonesia," https://www.aa.com.tr/id/budaya/kontrasnasib-dua-anak-pengungsi-diindonesia/968757. Accessed 20 October 2020.

[36]. NR Asti and SL Rahayu, "PemenuhanHak Pendidikan Anak bagi Pencari Suaka yang Transit di Indonesia Sembari Menunggu Status Pengungsi," Belli Ac Pacis, vol. 5, no. 1, pp. 1-8, Jun. 2019. 